\title{
Perbedaan Kadar Osteoprotegerin Serum Penderita Diabetes Melitus Tipe 2 tanpa dan dengan Penyakit Jantung Koroner
}

\author{
Ratri Dwitiya Nestiti, ${ }^{1}$ Noormartany, ${ }^{2}$ Nina Susana Dewi, ${ }^{2}$ Sylvia Rachmayati ${ }^{2}$ \\ ${ }^{1}$ Rumah Sakit Umum Daerah Al-Ihsan Kabupaten Bandung, ${ }^{2}$ Departemen Patologi Klinik Fakultas Kedokteran \\ Universitas Padjadjaran/Rumah Sakit Dr. Hasan Sadikin Bandung
}

\begin{abstract}
Abstrak
Diabetes melitus (DM) tipe 2 merupakan diabetes yang disebabkan oleh resistensi insulin dan atau gangguan sekresi insulin sehingga menyebabkan hiperglikemia yang merupakan penyebab disfungsi endotel. Disfungsi endotel merupakan proses awal aterosklerosis dan merupakan salah satu faktor risiko yang menyebabkan penyakit jantung koroner (PJK). Sampai saat ini angiografi koroner digunakan sebagai baku emas PJK. Pemeriksaan osteoprotegerin (OPG) merupakan pemeriksaan alternatif sebagai penanda disfungsi endotel, kurang invasif, lebih dini, dan murah. Osteoprotegerin berhubungan dengan perkembangan plak arteri pada penderita DM tipe 2. Tujuan penelitian ini mengetahui perbedaan kadar OPG dalam serum penderita DM tipe 2 tanpa dan dengan PJK. Penelitian dilakukan pada September-Desember 2012 di Poliklinik Endokrin dan Instalasi Gawat Darurat RSUP Dr. Hasan Sadikin Bandung. Subjek penelitian sebanyak 102 orang, 51 orang penderita telah didiagnosis oleh klinisi sebagai penderita DM tipe 2 dengan PJK dan 51 orang penderita DM tipe 2 tanpa PJK, berusia 35-75 tahun. Pemeriksaan OPG menggunakan metode enzyme linked immunosorbent assay (ELISA). Bentuk penelitian adalah observasional komparatif dengan rancangan penelitian studi perbandingan potong lintang. Analisis statistik menggunakan uji Shapiro Wilk's, independent T, dan Mann Whitney. Nilai median kadar OPG serum untuk penderita DM tipe 2 dengan PJK lebih tinggi, yaitu sebesar 6,1 pmol/L dan penderita DM tipe 2 tanpa PJK, yaitu sebesar 2,6 pmol/L ( $p=0.0001)$. Simpulan, terdapat perbedaan kadar OPG serum antara kelompok DM tipe 2 tanpa dan dengan PJK. [MKB. 2015;47(4):218-23]
\end{abstract}

Kata kunci: Disfungsi endotel, DM tipe 2, osteoprotegerin

\section{Differences of Osteoprotegerin Levels in Patients with Type 2 Diabetes Mellitus with and without Coronary Arterial Disease}

\begin{abstract}
Type 2 diabetes mellitus (DM) is caused by insulin resistance and/or impaired insulin secretion, thus causing hyperglycemia leading to endothelial dysfunction. Endothelial dysfunction is an early process of atherosclerosis and is one of the risk factors for coronary arterial disease (CAD). Currently, coronary angiography is used as the gold standard for diagnosing CAD. Examination of osteoprotegerin (OPG) is an alternative assay for endothelial dysfunction marker which is less invasive, has the ability to detect earlier, and less expensive. Osteoprotegerin is associated with the development of arterial plaque in patients with type 2 DM. The aim of this study was to determine the differences in serum OPG levels in patients with type 2 DM with and without CAD. The study was conducted in September-December 2012 in the Endocrine Clinic and Emergency Unit of Dr. Hasan Sadikin General Hospital Bandung on 102 patients aged between 35-75 years, with 51 subjects type 2 DM patients with CAD and 51 subjects with type 2 DM without CAD, both diagnosed by clinician. The method used was, OPG enzyme linked immunosorbent assay (ELISA) examination method. The study was an observational cross-sectional comparative study. Statistical analysis was performed using normality test with Shapiro Wilk's, independent T and Mann Whitney test. The median value for patients with type 2 DM with CAD equaled to $6.1 \mathrm{pmol} / \mathrm{L}$ and the value for type 2 diabetic patients without CAD was $2.6 \mathrm{pmol} / \mathrm{L}$. In this study, the OPG levels obtained in patients type $2 \mathrm{DM}$ with CAD were higher than those without CAD. In conclusion, there is a significant difference in OPG levels between type 2 DM with and without CAD groups. [MKB. 2015;47(4):218-23]
\end{abstract}

Key words: Endothelial dysfunction, type 2 diabetes, osteoprotegerin

Korespondensi: Ratri Dwitiya Nestiti, dr., SpPK., M.Kes,Rumah Sakit Umum Daerah Al-Ihsan Kabupaten Bandung. Jalan Ki Astramanggala Baleendah, Bandung, Jawa Barat 40381, mobile 082216622261, e-mail ratri.dwitiya@gmail.com 


\section{Pendahuluan}

Diabetes melitus atau DM merupakan keadaan kronis yang berhubungan dengan tingginya kadar glukosa dalam darah. American Diabetes Association (ADA) tahun 2011 menyatakan DM dibagi menjadi 4 tipe, yaitu DM tipe 1, DM tipe 2, DM tipe lain, dan diabetes kehamilan. Diabetes melitus tipe 2 adalah diabetes yang disebabkan oleh resistensi insulin dan atau gangguan sekresi insulin dan merupakan diabetes yang paling banyak terjadi, yaitu sekitar $90 \%{ }^{1}$

World Health Organization telah memprediksi bahwa kenaikan jumlah penderita DM tipe 2 di Indonesia dari 8,4 juta pada tahun 2000 menjadi sekitar 21,3 juta pada tahun 2030. International Diabetes Federation (IDF) pada tahun 2009 telah memprediksi kenaikan jumlah penderita DM di Indonesia dari 7 juta pada tahun 2009 menjadi 12 juta pada tahun 2030. Penderita DM di Jawa Barat diperkirakan 5,6\% penduduknya. ${ }^{2}$

Aterosklerosis pada penderita DM mampu mengenai organ jantung dan plak aterosklerosis merupakan penyebab paling banyak terjadinya penyakit jantung koroner atau $\mathrm{PJK}^{3}$ Penyakit jantung koroner ialah penyakit yang disebabkan oleh penyempitan pembuluh darah yang dapat menyebabkan berkurangnya aliran darah yang membawa oksigen ke jantung. ${ }^{4}$ Juutilainen dkk. ${ }^{5}$ menyatakan sebesar $68 \%$ penderita penyakit jantung diakibatkan komplikasi dari diabetes dan dapat menyebabkan kematian.

Angka kejadian DM tipe 2 di Rumah Sakit Dr. Hasan Sadikin Bandung (RSHS) pada tahun 2011 yaitu sebanyak 11.632 orang dan periode Januari-Agustus 2012 sebanyak 7.650 orang. Angka kejadian penderita DM tipe 2 dengan PJK di RSHS tahun 2011 sebanyak 1,66\% dan bulan Januari-Agustus 2012 sebanyak 1,11\%. American Heart Association (AHA) menetapkan angiografi koroner merupakan baku emas untuk pemeriksaan PJK. Tindakan angiografi koroner yang dilakukan di RSHS tahun 2011 sebanyak 70 kasus dan bulan Januari-Juni 2012 sebanyak 49 kasus menurut rekam medis RSHS tahun 2012.

Saatiniterdapatpemeriksaan osteoprotegerin (OPG) yang dapat digunakan sebagai penanda disfungsi endotel pada PJK. ${ }^{6}$ Pengambilan bahan pemeriksaan bersifat kurang invasif, lebih dini, dan biaya lebih murah. ${ }^{7}$ Sumber OPG terbesar pada arteri berasal dari sel endotel dan sel otot polos. Osteoprotegerin diproduksi pula oleh kardiovaskuler, ginjal, hati, otak, dan tulang serta plasenta. Osteoprotegerin (OPG) merupakan reseptor sitokin, anggota dari superfamili tumor necrosis factor (TNF). Osteoprotegerin mampu dideteksi pada pembuluh darah normal dengan nilai normal 2,99 pmol/L. Penelitian Ueland dkk. $^{8}$ bahwa kadar OPG serum lebih tinggi pada penderita diabetes melitus dibanding dengan tanpa DM. Penelitian Shin dkk. ${ }^{9}$ menyatakan bahwa terdapat hubungan disfungsi endotel pada penderita DM tipe 2 dengan peningkatan kadar OPG.

Penelitian Wu dkk.$^{10}$ bahwa kadar OPG serum lebih tinggi pada wanita Cina dibanding dengan wanita Austria sehingga kadar OPG dipengaruhi oleh perbedaan ras. Berdasarkan latar belakang di atas maka peneliti tertarik meneliti perbedaan kadar OPG penderita DM tipe 2 tanpa dan dengan PJK di RSHS Bandung. Sampai saat ini penelitian OPG pada DM tipe 2 dengan dan tanpa PJK belum pernah dipublikasikan di Indonesia.

\section{Metode}

Penelitian dilakukan pada bulan SeptemberDesember 2012 di Poliklinik Endokrin dan Instalasi Gawat Darurat RSHS Bandung. Bentuk penelitianiniadalah observasional menggunakan rancangan penelitian potong lintang. Kriteria inklusi adalah penderita DM tipe 2 yang telah didiagnosis oleh klinisi dan berusia 35-75 tahun. Kriteria eksklusi adalah penderita gagal ginjal akut, gangguan hati akut, dan penderita kelainan tulang. Variabel bebas adalah penderita DM tipe 2 tanpa dan dengan PJK. Variabel tergantung adalah kadar osteoprotegerin. Analisis statistik awal menggunakan Shapiro Wilk's untuk menguji normalitas data. Data berdistribusi normal maka digunakan analisis parametrik menggunakan uji independent $T$, sedangkan bila data berdistribusi tidak normal maka menggunakan analisis nonparametrik uji Mann Whitney. Hasil uji statistik dianggap bermakna bila nilai $\mathrm{p}<0,05$.

\section{Hasil}

Karakteristik penderita yaitu dari 102 subjek penelitian diperoleh hasil pada kelompok DM tipe 2 tanpa PJK (51 orang), lebih banyak perempuan dibanding dengan laki-laki, dan pada kelompok DM dengan PJK (51 orang) lebih banyak lakilaki dibanding dengan perempuan. Berdasarkan hasil analisis statistik dapat disimpulkan tidak terdapat perbedaan bermakna pada DM tipe 2 tanpa dan dengan PJK berdasarkan jenis kelamin.

Berdasarkan pembagian empat kelompok usia diperoleh hasil pada kelompok DM tipe 2 tanpa dan dengan PJK didapatkan paling banyak 
Tabel 1 Karakteristik Subjek Penelitian

\begin{tabular}{lccc}
\hline \multirow{2}{*}{ Karakteristik } & \multicolumn{2}{c}{ Kelompok Penelitian } & \multirow{2}{*}{ Uji Statistik (p) } \\
\cline { 2 - 3 } & DM Tipe 2 tanpa PJK & DM Tipe 2+PJK & \\
\cline { 2 - 3 } Jenis kelamin & & $\mathbf{n}(\%)$ & \multirow{2}{*}{0,111} \\
Laki-laki & $24(47,1)$ & $32(62,7)$ & \\
Perempuan & $27(52,9)$ & $19(37,3)$ & \multirow{2}{*}{0,205} \\
Usia (tahun) & $2(3,92)$ & $5(9,80)$ & \\
$<50$ & $16(31,37)$ & $18(35,29)$ & \\
$50-59$ & $22(43,13)$ & $20(39,21)$ & \\
$60-69$ & $11(21,56)$ & $8(15,68)$ & \\
$\geq 70$ & 62,25 & 60,24 & \\
Rata-rata $( \pm)$ & 48 & 38 & \\
Minimum & 74 & 75 & \\
Maksimum & & & \\
Lama DM (tahun) & 5,31 & 3,69 & \\
Rata-rata $( \pm)$ & 1 & 1 & \\
Minimum & 12 & 10 & \\
Maksimum & & & \\
\hline
\end{tabular}

Keterangan: DM=diabetes melitus; PJK=penyakit jantung koroner; $\mathrm{p}=$ probability bermakna bila $\mathrm{p}<0,05$

penderita berusia 60-69 tahun. Berdasarkan analisis uji statistik menunjukkan tidak terdapat perbedaan bermakna antara kelompok DM tipe 2 tanpa PJK dan kelompok DM tipe 2 dengan PJK.

Berdasarkan lama menderita DM (dalam tahun) lebih lama pada kelompok DM tipe 2 tanpa PJK, yaitu 5,31 tahun dibanding dengan dengan PJK, yaitu 3,69 tahun. Berdasarkan hasil analisis statistik didapatkan perbedaan yang bermakna antara kelompok DM tipe 2 tanpa dan dengan PJK. Diagnosis DM tipe 2 ditegakkan oleh klinisi berdasarkan atas kriteria ADA, yaitu berdasarkan kadar glukosa darah puasa atau kadar glukosa darah 2 jam pp atau kadar HbA1c.

Perbandingan kadar glukosa darah puasa pada kelompok DM tipe 2 tanpa PJK didapatkan lebih rendah dibanding dengan kadar glukosa darah puasa pada kelompok DM tipe 2 dengan PJK. Berdasarkan hasil analisis uji statistik maka didapatkan tidak terdapat perbedaan bermakna kadar glukosa darah puasa antara kelompok DM tipe 2 tanpa dan dengan PJK.

Tabel 2 Perbandingan Glukosa Darah Puasa dan Glukosa Darah 2 Jam Post Prandial

\begin{tabular}{lccc}
\hline \multirow{2}{*}{ Pemeriksaan } & \multicolumn{2}{c}{ Kelompok Penelitian } & p \\
\cline { 2 - 4 } & DM Tipe 2 tanpa PJK & DM Tipe 2+PJK & 0,354 \\
Glukosa darah puasa & 153,33 & 158,92 & 95 \\
Rata-rata ( \pm ) & 71 & 374 & 0,290 \\
$\quad$ Minimum & 485 & & \\
Maksimum & & 218,76 & \\
Glukosa darah 2 Jam PP & 206,12 & 114 & 457 \\
Rata-rata ( \pm ) & 51 & 471 & \\
Minimum & 476 \\
Maksimum &
\end{tabular}

Keterangan: DM=diabetes melitus; PJK=penyakit jantung koroner ; $\mathrm{p}=$ probability, bermakna bila $\mathrm{p}<0,05$ 
Tabel 3 Pemeriksaan Kadar OPG

\begin{tabular}{lccc}
\hline \multirow{2}{*}{$\begin{array}{c}\text { Pemeriksaan } \text { OPG } \\
\text { (pmol/L) }\end{array}$} & \multicolumn{2}{c}{ Kelompok Penelitian } & p \\
\hline Median & 2,6 & DM Tipe 2 dengan PJK & 0,0001 \\
Minimum & 0,20 & 6,1 & \\
Maksimum & 10,70 & 1,50 & \\
\hline
\end{tabular}

Keterangan: $\mathrm{OPG}=$ osteoprotegerin; $\mathrm{DM}=$ diabetes melitus; $\mathrm{PJK}=$ penyakit jantung koroner; $\mathrm{p}=$ probability, bermakna bila $\mathrm{p}<0,05$

Kadar glukosa darah 2 jam post prandial pada kelompok DM tipe 2 tanpa PJK didapatkan kadar lebih rendah dibanding dengan kelompok DM tipe 2 dengan PJK. Berdasarkan hasil analisis uji statistik tidak terdapat perbedaan bermakna kadar glukosa darah 2 jam pp antara kelompok DM tipe 2 tanpa dan dengan PJK. Nilai median pada penderita DM tipe 2 dengan PJK adalah 6,1 pmol/L dan nilai median penderita DM tipe 2 tanpa PJK adalah 2,6 pmol/L.

\section{Pembahasan}

Hasil penelitian berdasarkan lama menderita DM tipe 2 didapatkan DM tipe 2 dengan PJK lebih pendek, yaitu 3,69 tahun dibanding dengan DM tipe 2 tanpa PJK rata-rata, yaitu 5,31 tahun. Hasil penelitian sesuai dengan penelitian Avignon dkk. $^{11}$ yang menyatakan lama menderita DM tipe 2 tanpa silent myocardial ischemia (SMI) lebih lama, yaitu 16,8 tahun dibanding DM tipe 2 dengan SMI, yaitu 12,9 tahun. Berdasarkan teori banyak faktor yang dapat memengaruhi lama menderita DM tipe 2, yaitu usia, jenis kelamin, terapi diabetes, terapi statin, merokok, hipertensi, dislipidemia, dan juga terkontrol atau tidaknya kadar glukosa dengan pemeriksaan HbA1c. ${ }^{9}$ Lama menderita DM tipe 2 dengan PJK lebih pendek pada penelitian ini kemungkinan disebabkan oleh kurangnya kepatuhan penderita pada waktu kontrol ${ }^{12}$ penggunaan terapi serta diet pada penderita DM tipe 2 dengan PJK, namun pada penelitian ini tidak dilakukan pemeriksaan HbA1c karena ada keterbatasan biaya sehingga menyebabkan waktu yang lebih pendek untuk terjadi DM tipe 2 dengan komplikasi PJK.

Hasil penelitian kadar glukosa darah puasa pada kelompok DM tipe 2 tanpa PJK lebih rendah dibanding dengan kelompok DM tipe 2 dengan PJK. Berdasarkan hasil analisis uji Mann-Whitney dengan derajat kepercayaan 95\% diperoleh hasil $p=0,354$ menunjukkan tidak terdapat perbedaan bermakna kadar glukosa darah puasa antara kelompok DM tipe 2 dan tanpa PJK.

Kadar glukosa darah puasa lebih tinggi pada penderita DM dengan PJK dibanding dengan penderita DM tanpa PJK, namun secara statistik tidak bermakna. Hasil penelitian sesuai dengan penelitian Rhee dkk. ${ }^{12}$ dengan subjek penelitian penderita penyakit jantung koroner dengan dan tanpa penyempitan pembuluh darah dengan DM tipe 2 didapatkan kadar glukosa darah puasa yaitu, $110,15 \pm 41,91 \mathrm{mg} / \mathrm{dL}, 110,53 \pm 39,73 \mathrm{mg} /$ $\mathrm{dL}$, dan $\mathrm{p}=0,253$ sehingga menunjukkan tidak terdapat perbedaan bermakna kadar glukosa darah puasa. Berdasarkan kadar glukosa darah 2 jam pp pada kelompok DM tipe 2 dengan PJK lebih tinggi dibanding dengan kelompok DM tipe 2 tanpa PJK. Berdasarkan hasil analisis uji Mann-Whitney dengan derajat kepercayaan 95\% diperoleh hasil $\mathrm{p}=0,290$ memperlihatkan tidak terdapat perbedaan bermakna kadar glukosa 2 jam pp antara kelompok DM tipe 2 tanpa PJK dan kelompok DM tipe 2 dengan PJK. Kadar glukosa darah 2 jam pp pada kelompok DM tipe 2 dengan PJK lebih tinggi dibanding dengan kelompok DM tipe 2 tanpa PJK, namun tidak bermakna secara statistik. Hasil penelitian sesuai dengan penelitian Monnier dan Colette ${ }^{13}$ bahwa kadar glukosa darah 2 jam pp merupakan pemeriksaan untuk mengetahui status hiperglikemia secara keseluruhan terkontrol atau tidak pada penderita DM tipe 2. Pemeriksaan glukosa 2 jam pp dapat menggambarkan keadaan impaired glucose tolerance sehingga dapat dipergunakan untuk menilai risiko komplikasi diabetes. Penderita DM tipe 2 mengalami hiperglikemia kronik yang dapat mengakibatkan terbentuknya advanced glycation end product (AGEs) sehingga memicu stres oksidatif. Stres oksidatif akan menurunkan fungsi NO dan menyebabkan disfungsi endotel. Disfungsi endotel akan mengubah dinding pembuluh darah sehingga dapat mengakibatkan aterosklerosis. Aterosklerosis merupakan salah satu faktor risiko dapat menyebabkan PJK pada DM tipe $2 .{ }^{14}$

Hasil penelitian pada penderita DM tipe 2 
tanpa dan dengan PJK yang diperiksa kadar OPG karena berdistribusi tidak normal maka hanya nilai median yang diperoleh. Nilai median untuk penderita DM tipe 2 dengan PJK, yaitu sebesar 6,1 $\mathrm{pmol} / \mathrm{L}$ dan nilai median penderita DM tipe 2 tanpa PJK sebesar 2,6 pmol/L, dari hasil tersebut didapatkan nilai median pada penderita DM tipe 2 dengan PJK lebih tinggi dibandingkan dengan tanpa PJK. Penderita DM tipe 2 tanpa PJK terdapat seorang penderita yang memiliki kadar OPG yang tinggi, yaitu 10,7 pmol/L. Hal ini kemungkinan bahwa penderita sudah mengalami aterosklerosis karena sudah menderita DM selama 12 tahun, namun belum disertai gejala PJK.

Hasil penelitian ini, penderita DM tipe 2 dengan PJK didapatkan 11 orang yang memiliki nilai OPG sama dengan dan di bawah nilai median DM tipe 2 tanpa PJK. Hal ini kemungkinan karena penderita DM tipe 2 dengan PJK menggunakan obat simvastatin. Hal ini sesuai dengan penelitian Birgitte dkk. ${ }^{15}$ dengan subjek penderita DM tipe 2 yang berisiko menderita penyakit jantung dan diberi terapi simvastatin selama 18 minggu didapatkan penurunan kadar OPG, yaitu dari $1,961 \pm 1,31 \mathrm{pg} / \mathrm{mL}$ menjadi $1,816 \pm 0,95 \mathrm{pg} /$ $\mathrm{mL}$ setelah 18 minggu mendapat pengobatan simvastatin. Simvastatin mempunyai sifat antiinflamasi, menghambat molekul adhesi, TNF- $\alpha$, serta nuclear factor kappa $B$ (NF-KB) sehingga dapat mengurangi kalsifikasi vaskular yang dapat menurunkan kadar OPG. Berdasarkan teori DM tipe 2 merupakan keadaan hiperglikemia kronik yang mampu mengakibatkan disfungsi endotel sehingga meningkatkan ekspresi OPG, stres oksidatif, dan peningkatan NF-KB sehingga dengan pemberian terapi simvastatin, mampu menghambat peningkatan NF-KB, stres oksidatif yang pada akhirnya akan memperbaiki keadaan disfungsi endotel ${ }^{16}$ Hasil penelitian ini terdapat 4 orang penderita DM tipe 2 dengan PJK yang telah mendapat pengobatan simvastatin, tetapi kadar OPG-nya tetap tinggi, kemungkinan karena penderita tersebut tidak mengonsumsi obat secara teratur. Simpulan, terdapat perbedaan kadar OPG antara kelompok DM tipe 2 tanpa dan dengan PJK.

\section{Daftar Pustaka}

1. Association AD. Standards of medical care in diabetes. Diabetes Care. 2012;35(Suppl 1): S4-10.

2. PERKENI. Konsensus Pengelolaan dan pencegahan diabetes melitus tipe 2 di
Indonesia. Jakarta: PERKENI; 2011.

3. Scobie IN, penyunting. Chronic complications of diabetes. Atlas diabetes mellitus. Edisi ke3. London: CRC Press; 2007.

4. Venuraju SM, Yerramasu A, Corder R, Lahiri A. Osteoprotegerin as a predictor of coronary artery disease and cardiovascular mortality and morbidity. J Am Coll Cardiol. 2010;55(19):2049-61.

5. Juutilainen A, Rönnemaa T, Pyörälä K, Laakso M. Diabetes as a coronary heart disease equivalent. Diabetes Care. 2005;28(12):2901-7.

6. Knudsen ST, Foss CH, Poulsen PL, Andersen $\mathrm{NH}$, Mogensen CE, Rasmussen LM. Increased plasma concentrations of osteoprotegerin in type 2 diabetic patients with microvascular complications. Eur J Endocrinol. 2003;149 (1):39-42.

7. Ford ML, Smith ER, Tomlinson LA, Chatterjee PK, Rajkumar C, Holt SG. FGF23 and osteoprotegerin are independently associated with myocardial damage in chronic kidney disease stages 3 and 4 . Another link between chronic kidney disease-mineral bone disorder and the heart. Nephrol Dial Transplant. 2012;27(2):72733.

8. Ueland $\mathrm{T}$, Jemtland $\mathrm{R}$, Godang $\mathrm{K}$, Kjekshus J, Hognestad A, Omland T, dkk. Prognostic value of osteoprotegerin in heart failure after acute myocardial infarction. J Am College Cardiol. 2004;44(10):1970-6.

9. Shin JY, Shin YG, Chung CH. Elevated serum osteoprotegerin levels are associated with vascular endothelial dysfunction in type 2 diabetes. Diabetes Care. 2006;29(7):1664-6.

10. Wu X-Y, Wu X-P, Xie H, Zhang H, Luo X-H, Liu S-P, dkk. Relationship between age-related reference values of serum osteoprotegerin and leptin in native Chinese women and compared with those in women of other races. Clinica Chimica Acta. 2008;389(12):72-8.

11. Avignon A, Sultan A, Piot C, Mariano D, Franc J, Paul J, dkk. Osteoprotegerin: a novel independent marker for silent myocardial ischemia in asymptomatic diabetic patients. Diabetes Care. 2007;30(11):2934-9.

12. Rhee EJ, Lee WY, Kim SY, Kim BJ, Sung KC, Kim BS, dkk. Relationship of serum osteoprotegerin levels with coronary artery disease severity, left ventricular hypertrophy and C-reactive protein. Clin Sci. 2005;108(3):237-43.

13. Monnier L, Colette C, Owens D. Postprandial 
Ratri: Perbedaan Kadar Osteoprotegerin Serum Penderita Diabetes Melitus Tipe 2 tanpa dan dengan Penyakit Jantung Koroner

and basal glucose in type 2 diabetes: assessment and respective impacts. Diabetes Technol. 2011;13(1):25-32.

14. Bornfeldt KE, Tabas I. Insulin resistance, hyperglycemia, and atherosclerosis. Cell Metabol. 2011;14(5):575-85.

15. Nellemann B, Gormsen LC, Dollerup J, Schmitz O, Mogensen CE, Rasmussen LM, dkk. Simvastatin reduces plasma osteoprotegerin in type 2 diabetic patients with microalbuminuria. Diabetes Care. 2007;30(12):3122-4.

16. Secchiero P, Corallini F, Pandolfi A, Consoli A, Candido R, Fabris B, dkk. An increased osteoprotegerin serum release characterizes the early onset of diabetes mellitus and may contribute to endothelial cell dysfunction. Am J Pathol. 2006;169(6):2236-44. 